\title{
Herpes Zoster ophthalmicus with occulomotor nerve palsy
}

\section{Herpes zoster oftalmikus'a bağlı okulomatör sinir felci}

\author{
Gökhan Celbek ${ }^{1}$, Zehra Gürlevik², Âdem Güngörr ${ }^{1}$, Hülya Coşkun ${ }^{1}$, Hayati Kandiş ${ }^{3}$
}

J Clin Exp Invest 2010; 1(2): 141-142

Key words: Herpes zoster, ophtalmic, oculomotor nevre, palsy

\section{Dear Editor;}

A 79-year-old male patient was admitted to our emergency department with a complaining of eruption over his face for 10 days and inability to open his eyes for a few days. The patient had hypertension and diabetes mellitus. He had no history of smoking, alcohol. On examination, there was vesicular cutaneous eruption, erosions and crusts, as well as ptosis, in some areas in the ophthalmic division of the trigeminal nerve on the left side of his face (Figure 1). The patient did not have extraocular muscle palsy. Patient was cachectic and dehydrated appearance. Other systemic examinations were unremarkable. Laboratory investigations showed total white cell count of 16500 (neutrophil: $15000, \mathrm{~N}$ : 5200-12400), and CRP: $15 \mathrm{mg} / \mathrm{dL}$ (N: 0.1-0.5). A clinical diagnosis of ophthalmic zoster with occulomotor nerve palsy was made and the valasiclovir $3 \mathrm{~g} / \mathrm{d}$ was given to patient, wet dressing with an aluminum acetate solution $0,5 \%$. The patient's lesions had markedly improved within 10 days.

Varisella zoster is a DNA virus that usually affects the elderly and immunocompromised individuals. ${ }^{1}$ Varisella zoster virus causes vesicular rash (chickenpox) in children. After a period of latency in trigeminal ganglia, the virus is reactivated and causes the secondary infection known as herpes zoster. ${ }^{2}$ The prevalence of herpes zoster infections was $0.3-0.5 \%$. Herpes zoster ophthalmicus (HZO) represents about $10-15 \%$ of cases infected with herpes zoster virus. Vesicular eruptions of HZO usually develop in the periorbital area and forehead.
Klin Den Ar Derg 2010; 1(2): 141-142

Anahtar kelimeler: Herpes zoster, göz tutulumu, okülomotor sinir, felç

Approximately $1-5 \%$ of patients with herpes zoster develop motor weakness after dermatomal involvement. Trigeminal nerve is the most affected cranial nerve, but third and fourth cranial nerve involvement is rare in herpes zoster. ${ }^{3}$ Motor weakness occurs within 2 to 3 weeks after the onset of the rash. Ophthalmoplegia with herpes zoster ophthalmicus have been reported in the literature.. The ophthalmoplegia usually appears within 2 to 4 weeks after the onset of the rash, and is seen in $7-33 \%$ of patients with HZO. Multiple cranial nevre palsies can be observed simultaneously. However, pan ophthalmoplegia is an extremely rare complication. ${ }^{4}$ Third nerve palsy may present with a total or partial involvement, but ptosis always occur.

Here, we aimed to emphasize that the physicians should be familiar to the typical appearance of occulomotor nerve palsy.

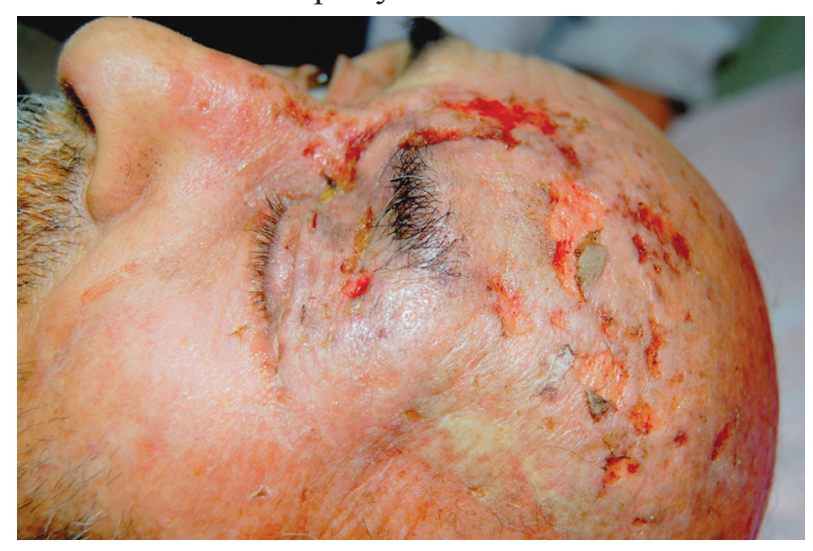

Figure 1. Crusts and erosions associated with erythema and peripheral vesicle on the periorbital area, forehead and nose

Duzce University Faculty Of Medicine, Departments of ${ }^{1}$ Internal Medicine, ${ }^{2}$ Dermatology, ${ }^{3}$ Emergency Medicine, Duzce, Turkey Yazıșma Adresi /Correspondence: Dr. Hayati KANDiș

Duzce University Faculty of Medicine Department of Emergency Medicine, Duzce, Turkey E-mail: hayatikandis@yahoo.com and kandis_78@hotmail.com Geliș Tarihi / Received:17.05.2010, Kabul Tarihi / Accepted: 15.07.2010 Copyright @ Klinik ve Deneysel Araștırmalar Dergisi 2010, Her hakkı saklıdır / All rights reserved 


\section{REFERENCES}

1. Shaikh S, Ta CN. Evaluation and management of herpes zoster ophthalmicus. Am Fam Physician 2002;66: 1723-30.

2. Bakbak B, Çelebi ARC, Şener C. Horner's Syndrome Following Herpes Zoster Ophthalmicus. Türk Nörol Derg 2009;15:82-4.
3. Pandey PK, Garg D, Bhatia A, Jain V. Horner's syndrome and sixth nevre palsy due to herpes zoster ophthalmicus arteritis. Eye 2005;19:224-6.

4. Yıldız ÖK, Seğmen H, Bolayır E, Topaktaş AS. A Case of Herpes Zoster Ophthalmicus With Oculomotor Nerve Palsy. J Neurol Sci [Turk] 2009; 26:500-4 